\title{
Adaptation of an educational ideal and refinement of the didactic strategies used in the management pedagogy in Romania
}

Cosmin-Florin Lehene 


\title{
Adaptation of an educational ideal and refinement of the didactic strategies used in the management pedagogy in Romania
}

\author{
Cosmin-Florin Lehene* a \\ ${ }^{a}$ Faculty of Psychology and Educational Sciences, Babeș-Bolyai University, 7 Sindicatelor Street, Cluj-Napoca, 400029, Romania \\ *Corresponding author: lehenecosmin@ymail.com
}

Abstract

Keywords: management pedagogy; educational ideal; didactic strategies
In this paper we discuss two potential problems in the management education in Romania: (1) the lack of alignment of the management pedagogues to the same direction in preparing the management students for the future and (2) the extrause of active-participative didactic strategies used by the management professors in specific management disciplines. Given two real-life situations, as a starting point, we elaborate and analyze some drawbacks and consequences these phenomena may have for the students enrolled in management education programs. Based on modern didactic principles and qualitative data analysis we propose then solutions to solve these problems and develop testable hypotheses which can be the subject of future statistical analyses for the improvement of the management education in Romania.
Zusammenfasung

Schlüsselworte:

Management-

Pädagogik;

pädagogisches Ideal;

didaktische

Strategien
In diesem Artikel werden zwei potenzielle Probleme in der Managementausbildung in Rumänien erörtert: (1) die mangelnde Ausrichtung der Managementpädagogen auf die gleiche Richtung bei der Vorbereitung der Managementstudenten auf die Zukunft und (2) der zusätzliche Einsatz von aktiv-partizipativer Didaktik Strategien, die die Managementprofessoren in bestimmten Managementdisziplinen anwenden. Ausgehend von zwei realen Situationen werden einige Nachteile und Konsequenzen erarbeitet und analysiert, die diese Phänomene für die in Managementprogrammen eingeschriebenen Studenten haben können. Basierend auf modernen didaktischen Prinzipien und qualitativen Datenanalysen schlagen wir Lösungen zur Lösung dieser Probleme vor und entwickeln überprüfbare Hypothesen, die Gegenstand zukünftiger statistischer Analysen zur Verbesserung der Managementausbildung in Rumänien sein können.

\section{Introduction}

Modern education can be seen as a set of activities devoted to the formation of new generations of citizens, through the dissemination of knowledge, development of abilities and behaviors, assimilation of values and cultural norms inherited by the society (Ionescu et al., 1995). According to Bocoş and Jucan (2019) there are many dimensions of education: intellectual education, moral education, religious education, professional education, esthetical education etc. One important dimension, in the contemporary context, is professional education. Particularly, the management education offered to the students in management or business schools. For instance, in Scimago Journal Rank (2019) in the first 50 journals according to their ranks, ten are economics, management or business-related journals. Management education could be seen as an educational activity organized at college/university level aiming to educate students for planning, organizing, leading people and controlling activities in organizations (Daft, 2010; Johns, 1996; Popa et.al., 2013).

In the field of pedagogy (Bocoș, Jucan, 2019; Ionescu et al., 1995) and particularly in socio-human pedagogy (Albulescu, Albulescu, 1999) have been established general principles regarding the modern pedagogy, have been described in greater detail the possible expositive and active-participative didactic strategies, the effectiveness and efficiency of each one and the circumstances under which these strategies may be suitable for application. Despite these well-established theories of teaching and learning, there is limited literature regarding how these general principles are actually applied by teachers of management. In other words, there is limited empirical evidence regarding the practice of teaching in one specific discipline. In our case, of management docents in management schools in Romania. 
On the other hand, as far as we know, there is no empirical evidence regarding the situations under which the use of the active-participative didactic strategies may be dysfunctional. Many academics underline again and again the importance of using active-participative didactic strategies at the expense of the expositive ones, even putting at the centre of modern didactic the use of activeparticipative strategies. In this context, the problem is that they do not take into account that in some circumstances the use of these interactive strategies may by dysfunctional. For example, in situations in which the teacher over-utilizes these didactic strategies and methods and only uses active-participative didactic strategies, neglecting the informative dimension of teaching as a whole.

This is the stream of research our paper contributes to. Based on two real-life situations, occurring at college/university level, we analyze the consequences these problematic situations may have for the learning achieved by the students on the one hand, and for the future performances of management graduates at their workplace on the other hand. Then, based on the real-life situation's analysis and on the existing literature in the fields of management and pedagogy we develop testable hypotheses regarding the improvement of management education in Romania.

Drawing upon the existing literature in the fields of pedagogy and management, the paper may be important for several reasons: (1) it helps the practice of management pedagogy at college/university level be improved; (2) it helps the operationalization of the educational ideal and educational scope be refined, through sketching clearer general educational objectives for management education, differentiating between highschools graduates and college/university graduates; (3) it helps to align the formation of management students to the same educational ideal and educational scope; (4) it provides a framework for guidance for the integration in the workforce of management graduates; (4) it sketches a logical pathway for future management graduates development along their careers.

Additionally, the assumptions discussed in this paper can be transferable also to other disciplines. For example, engineering. The engineering schools may also want to explicitly adopt an educational ideal and/ or may want to favour a balance regarding the utilization of expositive and active-participative didactic strategies. Perhaps, they will also notice, through a careful analysis, that in their school the use of active-participative strategies and methods are overutilized and the students are deprived by the informative benefits resulting from the implementation of the expositive type of teaching.

The rest of the paper is organized as follows. First, we begin by presenting the methodology we adopted in this paper. Then, based on the methodology adopted, we present the real life-situations for each topic of discussion and we analyze the possible dysfunctional consequences arising from each real-life situation. We propose then possible solutions to each situation and develop testable hypotheses which can be then the subject of future statistical analyses. We conclude by discussing this paper's limitations and we draw some possible lines of development for the future.

\section{Methodology}

In one sense, the scientific method used in this paper can be assimilated, to a certain degree, to the classical grounded theory method developed by Glaser and Strauss in 1967. The idea is the same as that proposed by the pioneering researchers in the 60 's - trying to build a new theory or help refine the existent one - starting from empirical data with observations, interviewing and being immersed in the local culture (Glaser, Straus 1967/2012). From another methodological perspective, the research methodology used in this paper can be assimilated also to the classical research methods used by ethnographers. According to classical ethnographers, one should be immersed in the local culture, observe the social interactions and behaviors of local people for various years in order to understand the social phenomena in its detail and complexity (Brannen, 1996; Van Mannen, 1979). Despite the fact that in this paper we try to implement some elements of case study research and ethnography, the research methodology cannot be assimilated to either tradition. Rather, we would classify this paper such as a review/ theoretical paper - the empirical evidence being used only as a starting point for the purpose of contextualizing and problematizing the subject of interest in order to favour the analysis and open the discussions.

The outcome is a set of testable hypotheses developed from empirical evidence - as suggested by Eisenhardt (1989) - and resulting after consulting the existent literature in the fields of pedagogy and management. Eisenhardt (1988, 1989), Gilbert (2005) developed entire 
new theories and developed new hypotheses starting with empirical data collected from various cases. The approach adopted in this paper is the same - developing some testable propositions from empirical data - but in our case the hypotheses are not developed from case study research. In this paper, the hypotheses are derived from real-life experiences, the researcher being immersed in the regional culture for many years. In other words, we developed some propositions as an output resulting from consulting the existent literature in the fields of pedagogy and management and after the application of some research methods and principles used in ethnography.

\section{Literature review and hypotheses development}

\subsection{The educational ideal problem}

\subsubsection{Conceptualization and the real-life situation analysis}

Education is not an activity developed randomly. All the educational activities have to achieve certain finalities (Ionescu et al., 1995). According to Miron Ionescu and collaborators (1995) the educational finalities can be divided in three levels: (1) the educational ideal - which synthesizes society's wishes and needs within a certain historical stage of development, postulating the social, psychological and pedagogical trends for the society development from a longer time perspective; (2) the educational scopes - representing educational finalities characterized by a medium level of abstraction, realizable in a shorter time, sketching specific scopes for education's profiles, schools, specializations or discipline; (3) the educational objectives - which represent specific educational finalities, formulated at the lowest level of abstraction, realizable after classes, sequences of classes or units of learning. From a sociohuman perspective, the educational finalities can be classified also depending on their nature in the following categories (Albulescu, Albulescu, 1999): cognitive objectives (such as the dissemination and assimilation of information and knowledge), cognitive-formative objectives (such as the development of intellectual abilities like memory, attention, reflexive critical thinking, perception, attribution, creativity), affective objectives (such as the formation and development of character, feelings, and attitudes toward a certain thing) and psychomotor objectives (such as the ability to apply the knowledge to solve a certain practical problem or the development of technical and technological manual operations).
For the purpose of this paper we will focus our attention on the first level: the educational ideal. According to the Education Law in Romania (2011) ",the educational ideal of the Romanian school is the free, harmonious and integrative development of human personality, the formation of individual personality, the assimilation of the cultural values of the society, values which should nurture the entrepreneurial spirit, the successful integration of the person in the society and into the labour market". In order to transpose this educational ideal to a specific segment or industry, an important problem of management pedagogy, at university level, is the lack of alignment of management teachers and/or colleges/universities offering management courses to a common educational ideal. These types of programs are designed to contribute, at least theoretically, and judging after the scientific content studied, to the formation of professional managers, able to effectively and efficiently administrate the organizations where they are going to work. In consequence, I would say that this should be, or could be, the educational ideal nurturing the formation of future generations of students enrolled in management studies.

The educational ideal spans beyond the limits of a specific college/university, locality or region. The educational ideal is formulated at the society's and national level and it is postulated in a manner able to include society's needs and wishes regarding the future generations of graduates (Ionescu et al., 1995). The problem is that this educational ideal postulated for education conducted in Romania, applied or projected to the management education, ideal which should be broadly assumed by the management schools and teachers, is not broadly disseminated or enough understood along management professors. We would say that even if there are some management teachers, within some business and management schools, teaching and guiding their students in a reverse direction, compared with the educational ideal mentioned above. To support this assumption let's look at the first real-life scenario.

\section{Scenario 1}

Let's assume that we are observers in a class taught to management graduate students. The class is conducted by the teacher in an active-participative way using didactic methods such as the heuristic dialog and collective academic debates. The subject of the didactic debate is the motivation of people at work. After asking some 
questions, one student - let's assume is the case of the Valedictorian - answered the question raised by the teacher saying:

"The theory $\mathrm{X}$ and theory $\mathrm{Y}$ represent a set of assumptions about the beliefs of managers regarding what motivates the people at work. The theory was developed by psychologist Douglas McGregor in 1958. We, as future managers, should understand these theories in order to better apply these principles in real-life companies." (Student, 25 years-old).

In this context, the teacher tells the student and the entire class the following statement:

"Whom told you that you are a manager when you finish the school? I heard you last year within the final festivity while you were saying in the graduation speech, we as future managers [...] You are not a manager when you finish the management school." (Management teacher, 45 years-old).

In our view, this is a career ending statement. All the students who attended the class felt confused regarding what they were doing there, why they have registered for this management specialization and how their future is going to look like after graduation. The management teachers should encourage and explicitly assume the educational ideal of management education: the formation of a new generation of managers; and help the management students be aware regarding their future job and prepare them in accordance with this educational ideal. Instead, this real-life situation suggests that some management pedagogues are completely misaligned with the curriculum taught and the vision of the program as a whole. This situation is similar with telling a law school graduate that he/ she is not going to be a lawyer after graduation, and he/ she will be instead a seller in a retailing shop. Or, telling a medical school graduate that he/ she will not be a MD (medical doctor) instead he/ she will be a cashier. I mean, cashier by profession. We would say that this is one of the reasons why some many management graduates end their studies and employ themselves in jobs such as secretaries, workers in construction - under their level of expertise - or end in unemployment. If they are not supported and if they are discouraged by their mentors what they will become?

In this line of thinking, we would say that the problem of adaptation of an educational ideal, at least in the management education, is a very sensible and important problem. The management educational ideal is different from the vision and mission of a specific program or management school. The educational ideal in management education should guide all the management programs in all the management schools and be embraced by all the management teachers in the direction of forming and developing professional managers for the future.

\subsubsection{Discussion and adaptation of an educational} ideal

This problem we would like to discuss in the beginning of the paper is one which may impact the management education in Romania as a whole. In Romania, the management as a scientific discipline, is taught in a systematic way starting at the college/ university level. There are specific bachelor and master programs designed to contribute to the understanding of the managerial work done in organizations by the students. However, many aspects related to the managerial work start earlier at the high school level, where the pupils are taking their first contact with the business world and the administration of firms and organizations. One can check the textbooks, accredited by the government, for teaching in high schools (Ministry of Education in Romania, 2019) and the formal planning and curriculum projection for high school technological education - available through the Institute for Educational Sciences In Romania (2019) - and see that all capture various facets of managerial activities done in organizations.

For instance, in Planificare operațională (Capotă et al. 2007; Ilie et al. 2006) the pupils enrolled in high schools take their first contact with fundamental managerial concepts such as organizational structure, organization's hierarchical levels, organization's objectives, resources analysis, types of production and more. In the same line of thinking, in Tehnologia turismului, Stănciulescu et al. (2003) discuss concepts and managerial problems related to operations management such as the internal organization of a tourism agency, the need to formulate a vision and mission for the new tourism agency, the authors even use concepts normally used in the strategic management. Also, in Mediul concurențial al afacerii, Ilie and collaborators (2007) make a step forward and even introduce the pupils to the environmental analysis, treating aspects such as the identification of firm's competitors and analysis, realization of a SWOT analysis, and adaptation of the classical Porter's models (1980) and 
(1985) for analyzing the industry. The idea is that all the authors mentioned above have started to apply and project managerial concepts, tools and methods, initially developed at university level for master and executive MBAs students, to the high school level.

According to the accredited textbooks (Ministry of Education in Romania, 2019) and the related formal planning mentioned above (Institute for Educational Sciences In Romania, 2019) the educational scope of these educational programs in high schools is to contribute to the formation of technicians in economic activities, technicians in tourism, technicians in hotels, technicians in commerce and services, banqueting organizer etc. Given these advances in curriculum projection and in the scientific content taught at the high school level - at the high school level there are various technicians in management related disciplines formed what we propose in this paper is that at the college/ university level the programs developed in the scientific domain Management should be specifically designed to form and develop professional managers. This should be the educational ideal for the management education in Romania. After graduating one management program at college/university level you are a manager. You are not a technician, operational worker, analyst or other related or unrelated professions.

Management is the administration of an organization, or division/ unit of an organization, being a business, NGOs, public institution, political party or other type of organization. In this line of thinking, managers are the employees who manage an organization (Daft, 2010; Johns, 1996). There are four fundamental activities constituting the managerial work: planning, organizing, leading and controlling (Popa et al., 2013). In this paper, we would like also to make an important distinction between the professional managers and the so-called amateur managers. There are two types of amateur managers: (1) managers without management formation and (2) managers resulting from other understandings and approaches regarding the concept management. In the first category, there are graduates from other disciplines related or totally unrelated to management - which think that they can do the manager's work without management formation. For example, an engineer or accountant promoted in a project management position without management education. In the second category, there are the managers in charge of specific tasks, which because of the lack of a better word/concept to describe their work they are title as managers. For example, relationship manager, communication manager etc. We saw many times, in the real life, the different understandings and utilization of the concepts management and manager. In this paper, we discuss about the management of an organization and managers working in organizations.

In this context, we would say that there are only three types of managers: first-line managers, middle managers and top managers/executives (Popa et al., 2013). When we refer to a manager, we refer to at least to a first-line manager. For example, a team leader, a head of office, a project manager. There are no other types of professional managers - in this perspective - beyond the fundamental categories: first-line managers, middle managers and top managers. If one employee cannot situate itself in one of these hierarchical positions, he is not a manager. Rather, he/she should be regarded as a non-manager employee, operational worker, technician, or analyst. Now that we have clarified the concept manager, we can say that the educational ideal of the management pedagogy in Romania should be related to the formation of professional managers. Not technicians, not analysts, not operational workers.

This assumption and adaptation of this educational ideal for the management education is also supported by the European Qualification Framework (European Commission, 2019) and International Standard Classifications of Education (UNESCO, 2019). According to these international directives and regulations the graduates and undergraduates from management colleges and universities should possess after graduation management knowledge at an advanced level and highly specialized skills in the managerial work. In this line of thinking, they could and should start immediately after graduation working in a small, medium or large company, in different managerial positions, depending their level of competences. Since the subject of the paper is the educational ideal and the projection/ operationalization of this educational ideal to a lower level of abstraction - educational scope and objectives next, we are going to provide some guidance regarding the pathways for integration in the workforce of the management graduates.

As one can see in the table no. 1, we would say that a graduate from a bachelor management program should occupy at least a first-line management position after graduation (e.g. team leader, operations manager, project 
manager, head of office, shop manager etc.). In the same time, a master graduate in management should be contracted for a middle level managerial position (e.g. HR manager, production manager, marketing manager, division manager, business unit manager etc.). There is a third category of management graduates: the graduates from Executive MBA programs. In this line of thinking, we would say that because they possess also some managerial experience they automatically should be contracted as executives/top managers (e.g. CEO, COO, Chief Strategy Officer, region/ country manager, plant manager etc.). Regarding this guidance we would not enter in detail regarding the scepticism which may arise because of the lack of experience. The discussion would be very long. We would say here only that the companies should hire based on competences and not on experience and the common sense.

The same approach as we describe in this paper is the subject of implementation in other disciplines. For instance, psychology. In psychology, academics and professionals are trying to make a clear distinction between accredited psychologists - for instance, through the Romanian Collegium of Psychologists - and other type of psychologists non-accredited. The admission into the Romanian Collegium of Psychologists is based on clear procedures and rules which the members should comply with (David, 2006). I would say that a similar approach should be implemented also in the managerial education. You are not a professional manager if you do not have the formal education carried out in one accredited management school. According to David (2006) the academic psychologists are doing also several steps in trying to provide a framework for the employment of future psychologists according to their level of studies. The procedures are similar with those discussed in this paper, differentiating the employment of the psychology graduates depending their level of expertise - bachelor, master or even doctorate.

Table no. 1. Guidance for integration in the workforce of management graduates

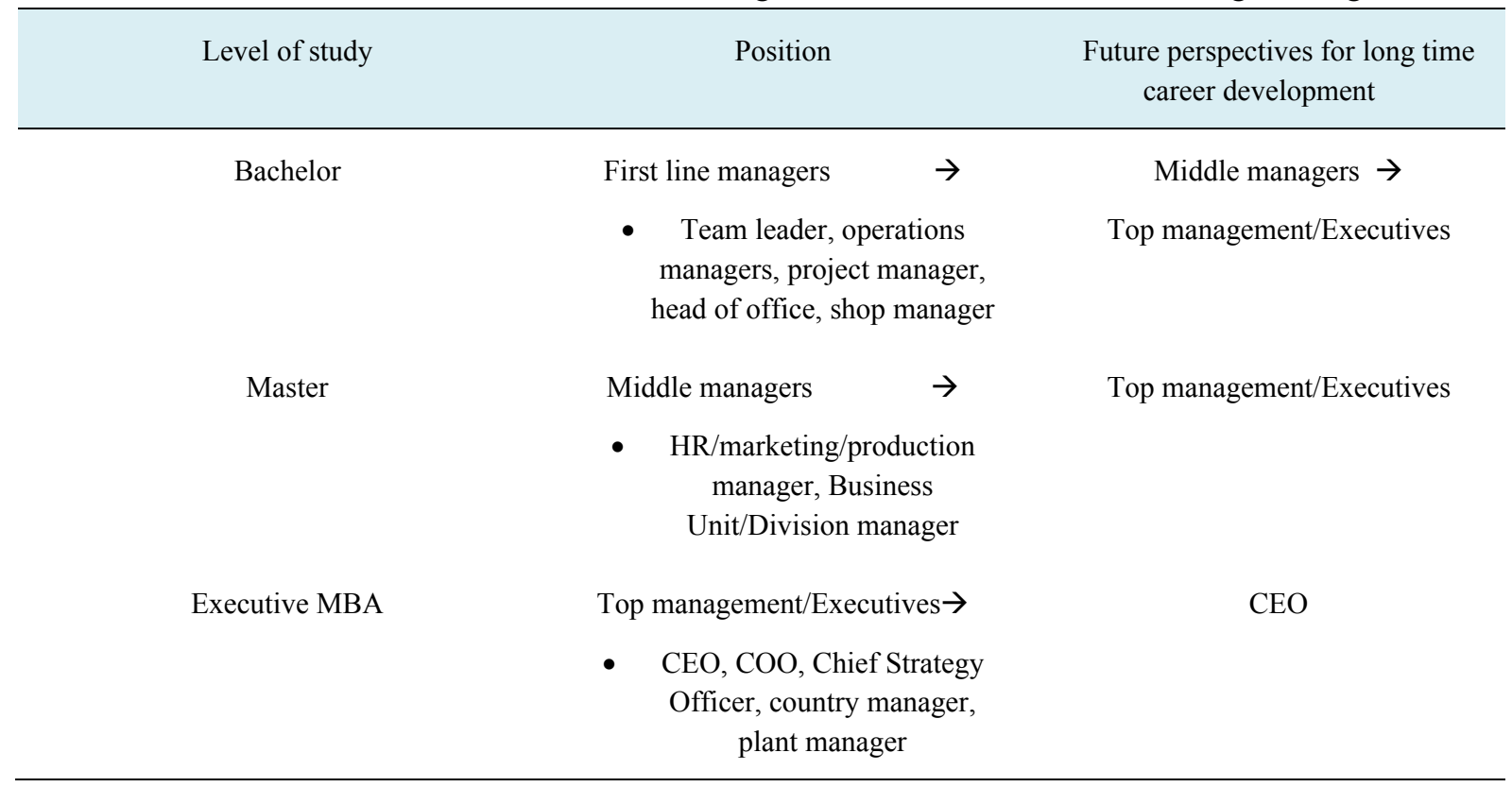

Through the alignment to a common educational ideal for the management education we do not refer to a socialist perspective or to other political views and ideologies which this concept may suggests. Instead, we refer to adopting a single direction for all the colleges and universities teaching management and perhaps more important, alignment of all management teachers to the same educational ideal. In this line of thinking, our ideas are supported by some recent findings. According to Porter (1998, 2003), Delgado et al. (2012) the competitive advantage of nations and regions comes from a regional perspective and alignment of the vision of the organizations operating into the region, under the same umbrella. Given Romania's affiliation to the UE we could assume that Romania should act as a region in the 
European market and should act as a single player beyond nation's regional differences.

Evidence tells us that on the one hand the organizations in the same region should partner in regional clusters. On the other hand, these should not develop completely misaligned with the national or regional strategy. Of course, organizations have the political and legal rights to develop as they like, we live in a free market economy and democracy, but Porter's and his colleagues' assumption is that we - as a region - are not going to be truly competitive if each organization seeks only its interests and if the vision of the regional players are not aligned under the same direction (Delgado et al., 2012; Porter, 1998, 2003). Our assumption is that we in Romania should align our vision regarding the management education under the same umbrella - and start developing from here - conceptualized here the educational ideal for the management education in Romania, education devoted specifically to the formation of new generations of managers.

Another contemporary concept is that of coopetition. Coopetition refers to collaboration and competition in the same time. Or, organizations which have convergent and divergent objectives (Bouncken et al., 2016; Tiessen and Liton, 2000). In this competitive orientation, each school it is necessary to continue to have its vision, mission and individual strategy in order to stay competitive in the market. Also, there should be promoted relationships between universities and colleges teaching management programs based on a strong competition. But what we are referring to in this paper is that all the management schools and teachers in Romania should adopt an educational ideal related to the formation of professional managers for the future.

The idea is that the management graduates should have a clear pathway to follow along their careers, specific objectives regarding their formation, and formal procedures for the future, similar to their colleagues in other disciplines. For instance, future psychologists, future policemen, future officers in the army, future medical doctors, all have a clear pathway to follow after they graduate the university. A recent graduate from Police Academy will start working as a police officer/ lieutenant/ sub-inspector not as a sergeant and she/ he will follow a clear pathway toward the top. Why is that in
Romania we cannot give our future management graduates a clear pathway and a clear guidance toward the future?

As a conclusion, there can be various benefits of the adaptation of an educational ideal for the management education. For instance, the adaptation of an educational ideal and the design of a clear pathway for career development will act as a school counselling service for the students. Earlier the students understand these pathways, better the ulterior performances obtained. In the same time, the adoption of an educational ideal: (1) may help better allocate the resources for preparing the future generations of managers, (2) may increase the integration of management graduates in the workforce in their specialization, (3) may help refine, optimize and improve the management education programs, (4) may help to align management schools' objectives with the business world scopes and intentions, (5) may help the business world to understand the pathways for starting and developing the careers of their managers. In conclusion, better managers for the future. Thus:

H1: There is a direct relationship between the assimilation of a management educational ideal along the teachers in management schools and the performance of the future generations of management graduates.

H2: There is a direct relationship between the assimilation of a management educational ideal along the teachers in management schools and the performance of the region as a whole.

\subsection{The problem with the extra-use of active- participative didactic strategies}

Other important topic in the management pedagogy is the relationship between the use of active-participative didactic strategies and methods such as the heuristic conversation, didactic dialog, problematization, or case studies (Ionescu et al., 1995), and the learning achieved by the students. The idea is that many management teachers have misunderstood the essence of these modalities for teaching and through mixing the methods they hope the students would learn in a modern way the scientific content, when in fact they don't. What they actually do is that some of them try to replace the classical lectures held by the docent with presentations held by 
students. In this modality, the scientific content is presented by the student and not by the teacher. It seems that what they have not understood is that the activeparticipative didactic strategies should complement the expositive ones, and not try to substitute or replace the expositive strategies. In support of this assumption, let's look to a second real-life scenario. In this scenario, we discuss how the extra-use of active-participative didactic strategies may in fact impoverish the learning to be achieved. This scenario is captured from reality but for confidentiality reasons we would not say the name of the institution where the case occurred and the actors involved.

\section{Scenario 2}

Let's say that for the discipline $\mathrm{X}$ the professor came to the class at the beginning of the semester and gives the students some textbooks to make essays regarding one specific topic they like. The students need to choose three topics which will be then presented - using a Power Point presentation - in three different classes. Next, starting with the second class, each week, according to the schedule drawn, some students need to prepare and present the essay elaborated. More specifically, each weak the class will consist of students' essay presentations and discussion on the essay elaborated. In this mode, the teacher hopes that can cover the entire curriculum through students' presentations. This is all the learning the students will experience during the semester for this discipline. The students, single or in groups, need to present three essays during the semester which will be then graded by the teacher, in order to establish the final note. In this scenario of teaching, the students are involved in the educational operations in order to prepare the class, the teacher is exempt from elaborating the didactic material and instead, acts as an evaluator and a facilitator only from the outside, acting in fact as a coach standing aside.

Despite the formative benefits this strategy may have, such as the development of cognitive and intellectual abilities, project writing abilities, critical thinking or public speaking abilities (Albulescu, Albulescu, 1999) there are both some important aspects neglected by the teachers using only this strategy for learning and important drawbacks. Firstly, despite the fact that some students may have developed already presentation and public speaking abilities some of them may experience problems to present their work, could be shy, or simply may encounter difficulties in presenting the scientific content. The goal of the class, as a whole, for each particular lesson, is that all the students would assimilate the scientific content as efficiently as possible. If during the lesson, let's say from four presentations three are presentations of bad quality, the learning performed by the class as regards the scientific content is almost nullified. For this reason, we would say that the scientific content cannot be delegated to the students, which in most of the cases do not have the presentation abilities that teachers have. More than that, for this reason, the teachers attend modules and programs devoted to the formation of teachers for the academic career.

Secondly, students may extract from the textbooks and present only the parts they like or they understand, and which fit with their interests. For example, if for a class in organizational behavior there are colleagues with a background in technical education and they are not familiar with the personality traits of persons they will synthesize and present only what they understand. Additionally, the presentation made by them can be very abstract and only skim the content at the surface. In the same time, some of them could not be very interested in developing presentation abilities and project writing abilities and be more interested in assimilating updated knowledge, in order to apply this knowledge in real-life companies after graduation. For these students, this strategy for teaching will have poor benefits, because they search for new information, valuable and updated. The formative abilities are not the priority for them as they look for the informative benefits of teaching. In this line of thinking, the problem with teaching only in this activeparticipative modality is that some important aspects in the curriculum could be omitted by the students and in consequence the learning achieved by the class would be, again, very poor.

Third, students could present the scientific content in an illogical and unsystematic way, according to their preferences and not according to the scientific rigor and the logic of the discipline. It means that students may elaborate essays on the topics they like and the scientific content which should be acquired by their colleagues during the essay's presentation could be mixed and not be presented in a systematic and logical manner. Using 
informative didactics methods such as lectures, exposures, or narratives the teachers could present the scientific content in a logical way, according to the formalized plan and according to the logic of the discipline. There is a greater probability that all the students will learn the essentials of a particular discipline if the scientific content is designed, elaborated and presented in a logical and systematically way by the professor. And back to our supposition, again, from the informative perspective, the learning achieved in this teaching scenario is very poor.

Fourthly, the students may simply introduce fake information/errors in the presentation. From another perspective, they may introduce in their essays and presentations their points of view, wittingly or unwittingly, which are based on the common sense and not supported by evidence as is the case of the scientific knowledge. Teachers who only supervise the presentation may not be aware of all the errors which can appear during the presentation. Probably, we cannot identify the errors transmitted in oral communication as well as we identify them in writing and when we devote time particularly to this task. If the teacher only supervises the oral presentations made by students and assume that all the information transmitted by the presenter is valid, the rest of the class may learn fake information and pseudoscience. Another reason in support of the assumption is that there should be also a clear expositive didactic strategy put in place in order to present the scientific knowledge to the students by the professor, in a systematic and logical way.

In this line of thinking, the presentations held by the students represent a powerful didactic method in order to develop their public speaking abilities, prepare them for the academic career, develop their interaction abilities and many other benefits. The individual or group elaboration of essays and projects, contributes also to the development of cognitive-formative abilities such as synthesis, analysis, induction, deduction, analogy, critical thinking, the development of convergent and divergent ideas (Albulescu, Albulescu, 1999). Nevertheless, the active-participative teaching strategy discussed above has an important contribution to the formation of specific abilities within the formative dimension of education. Given the arguments presented above, the author's assumption is not that this active-participative strategy is inefficient per see. The problem is that this strategy may be over-utilized and extra-used by some management teachers at the expense of the expositive related teaching strategies. In short, the author's preoccupation is that too much emphasizing has been given to teaching through active-participative didactic strategies, at the expense of the expositive ones, at least in the field of management.

In this paper we do not analyze the scientific content transmitted to the students or the quantity of the information disseminated through lectures. Of course, according to modern didactic principles only the most important realizations, aspects and essential information regarding the social life should be taught to the students (Albulescu, Albulescu, 1999). The idea is that this essential information is necessary to be disseminated to students and cannot be omitted or neglected by teachers. There should be implemented a clear and a logical expositive strategy, through which the students can learn the scientific content, together with the formative dedicated active-participative didactic strategies and methods.

In conclusion, if the goal of teaching and learning is, according to modern didactic principles, to keep a balance between the informative and formative nature of teaching, to contribute to both the achievement of cognitive objectives but also to the development of affective and psychomotor related abilities (Albulescu, Albulescu, 1999), to transmit the values and the knowledge embedded in the society (Bocoș \& Jucan, 2019; Ionescu et al., 1995), the teachers in the managerial education should not skip, neglect or omit the informative benefits and the power of exposures, lectures and narratives. The formative dimension of the management education should only complement the informative one, and not try to substitute or replace it.

In consequence, we would say that the learning achieved by the students in the management education and the performance of future management graduates in their workplace, educational finalities cultivated through an active-participative didactic strategy will grow until a certain point. After this point, the extra-use of activeparticipative methods will determine both the learning achieved by the students and the probability of future workplace performances to start decreasing. Thus: 
H3: There is an inverted U shape relationship between the use of active-participative didactic strategies and the learning achieved by students in the management education.

H4: There is an inverted $U$ shape relationship between the use of active-participative didactic strategies and the workplace performance of future management graduates.

\section{Limits and future avenues of research}

There are several limits regarding the assumptions and hypotheses developed in the paper. Some of them result from the methods themselves and some of them are related to the theories in pedagogy and management.

From a methodological perspective, the first limit has to do with the scarcity of the empirical evidence and the possibility of the uniqueness of the case. Both real-life situations described in the paper are based on real facts but for confidentiality motives the author did not want to give more details regarding the context and the authors involved. Also, the degree of use of active-participative strategies for teaching may differ in other universities, regions or countries. In other words, in other colleges/ universities offering management programs, other regions or countries, the management professors may use in equilibrium the expositive and the active-participative strategies. This equilibrium could be also maintained by other management teachers in the same institution. Therefore, not all the teachers in the same institution, i.e. teaching management, cultivate in an imbalanced manner the informative and formative dimensions of teaching and learning. Regarding the first topic in our discussion, the degree of management pedagogues aligning to the educational ideal described in this paper could be different. Some of them align more some of them less.

These limits may favour and represent starting points and/ or opportunities for the development of new studies (case studies, statistical analyses or questionnaires-based studies). For instance, there can be developed in-depth case studies in order to see why the teachers in management schools use only active-participative strategies at the expense of the expositive ones. Other studies can try to emphasize the degree of balance between the use of expositive and active-participative didactics strategies through a questionnaire applied to a sample of management teachers. In a similar direction, some studies can be developed in order to point out the degree of alignment of the management docents to the educational ideal developed in this paper.

Despite these important limitations, the paper has developed some important ideas and discussed some problems encountered in the management education in Romania. The propositions developed can be transferred to other contexts with careful consideration (Welch \& Piekkari, 2017) or can be sharpened, improved and be the subject of future statistical analyses (Eisenhardt, 1989; Eisenhardt \& Graebner, 2007). From the point of view of a research's lifecycle (Eisenhardt, 1989; Eisenhardt and Graebner, 2007) the position of this paper is exploratory implying a first step in trying to solve the problems in discussion. The propositions developed should stay at the base of future statistical analyses to see (1) if the lack of alignment to an educational ideal and (2) the extra-use of active-participative didactics strategies are not idiosyncratic phenomena.

\section{Conclusions}

In this paper we have discussed two important problems occurring in the management education in Romania. The first one is the lack of alignment of the formation of management students to the same educational ideal. We have proposed that the universities and colleges offering management programs should explicitly (1) mention that the objectives of the management programs are designed to contribute to the formation of a new generation of managers, (2) mention in their brochures, formalized plans and strategies the pathway their future management graduates may pursue along their career. Both solutions are regarded as operational tools/ solutions in order to implement and operationalize the educational ideal for the managerial education in Romania. The second problem brought into the debate was the fact that in some management schools the use of active-participative didactic strategies is overutilized/ extra-used. The author has suggested that in line with modern didactic principles there should be a balance/equilibrium between the informative and formative dimensions of the management education. A central idea is that the active-participative didactic strategies and methods should only complement the expositive oriented strategies and methods. The formative 
dimension should not try to replace or substitute the informative dimension. There are lots of benefits resulting from lectures, exposure, narratives and other expositive strategies and methods. Both problems were regarded and discussed in the context of the management education at college/ university level.

I will expect that many of you will criticize the paper regarding aspects such as: where is the rich evidence for what are you saying, how can you generalize these ideas to other contexts, how can we be sure that the situation is not idiosyncratic, how did you analyze the empirical data. To many of these questions, I hope I have provided already an answer within the methods and limits sections. However, I wish to remember the readers that the idea of this paper was to bring in discussion and in the attention of pedagogy and management researchers and teachers some drawbacks and problems occurring in teaching management at college/university level. I have tried to provide some ideas and solutions in order to solve these problems. The purpose was not to discuss why these situations occur - question suitable to be answered through an in-depth case study research strategy - nor in how many similar situations these problems occur question suitable to be answered by a questionnaire and/or statistical analysis of data (Yin, 1984/2014). Instead, what I have tried to do in the present manuscript was to bring in discussion some possible situations within which the use of active-participative didactic strategies is not appropriate and why the misalignment of the teaching management could hamper the learning achieved and the performance of future management graduates at their workplace. Despite the fact that we should continue promoting proactiveness, risk taking, innovativeness, a strong competition, in short, an entrepreneurial orientation (Bouncken et.al, 2014; Hitt et al., 2007) within and between management schools we should not forget that the management education in Romania should be aligned to a common educational ideal, designed to educate and develop new generations of managers.

\section{Authors note:}

Cosmin-Florin Lehene is a participant in the postgraduate psycho-pedagogical module at the Faculty of Psychology and Educational Sciences, Babeș-Bolyai University of Cluj-Napoca. He obtained a Ph.D. in
Management in 2018 at Babeș-Bolyai University. His research interests are interdisciplinary oriented covering two fundamental domains: management and management pedagogy. In the first domain, Cosmin-Florin Lehene is interested in various subjects related to the strategic management discipline (e.g. strategic alliances and partnerships between organizations, corporate governance, regional clusters, or the internationalization of companies). In the management education domain, his interests cover various facets, fundamental or applicative, related to studying pedagogy in management and business schools.

\section{References}

Albulescu, I., Albulescu, M. (1999). Didactica disciplinelor socio-umane. Cluj-Napoca: Napoca Star.

Bocoş, M., Jucan, D. (2019). Fundamentele pedagogiei. Teoria şi metodologia curriculumului. Repere şi instrumente didactice pentru formarea profesorilor, ediţia a IV-a, revizuită. Pitești: Editura Paralela 45.

Bouncken, R., Clauß, T., \& Fredrich, V. (2016). Product innovation through coopetition in alliances: Singular or plural governance?. Industrial Marketing Management, 53: 77-90.

Bouncken, R., Plüsche, B., Pesch, R. \& Kraus, S. (2014). Entrepreneurial orientation in vertical alliances: joint product innovation and learning from allies, Review of Managerial Science, 1-29.

Brannen, M.Y. (1996). Ethnographic International Management Research, in B.J. Punnett and O. Shenkar (eds.), Handbook for International Management Research, Cambridge: Blackwell, 115-143.

Capotă, V. (coord.) (2007). Planificare operațională. Bucureşti: Editura Akademos Art.

Daft, R. (2010). Understanding the theory and design of organizations. Mason, $\mathrm{OH}$ : South-Western Cengage Learning.

David, D. (2006). Psihologie clinică și psihoterapie: fundamente. Iași: Polirom.

Delgado, M., Ketels, C., Porter, M., \& Stern, S. (2012). The Determinants of National Competitiveness, National Bureau of Economic Research, Cambridge MA, 1-47.

Eisenhardt, K., Bourgeois, L.J. (1988). Politics of strategic decision making in high-velocity environments: Toward a midrange theory. Academy of Management Journal, 31(4): 737-70.

Eisenhardt, K.M. (1989). Building theories from case study research. Academy of Management Review, 14(4), 532-550.

Eisenhardt, K.M., Graebner, M.E. (2007), Theory building from cases: Opportunities and challenges. Academy of Management Journal, 50(1), 25-32.

Gilbert, C.G. (2005), Unbundling the Structure of Inertia: Resource Versus Routine Rigidity. Academy of Management Journal, 48(5): 741-763. 
Glaser, B.G., Strauss, A.L. [1967] (2012). The Discovery of Grounded Theory: Strategies for qualitative research. 7 th ed. New York: Aldine.

Hitt, M., Hoskisson, R. \& Ireland, D. (2007). Management of strategy. Concepts and Cases. Mason, $\mathrm{OH}$ : Thomson Higher Education.

Ionescu, M., Radu, I. (coord.) (1995). Didactica modernă. ClujNapoca: Dacia.

Ilie, C.S. (coord.) (2006). Planificare operațională. București: Editura Oscar Print.

Ilie, C.S. (coord.) (2007). Mediul concurential al afacerii. București: Editura Oscar Print.

Johns, G. (1996). Organizational Behavior. Understanding and Managing Life at Work. $4^{\text {th }}$ ed. New York: Harper Collins Publisher.

Popa, M., Lungescu, D., Salanță, I. (2013). Management: Concepte, Tehnici, Abilități. Cluj-Napoca: Editura Presa Universitară Clujeană.

Porter, M. (1980). Competitive Strategy: Techniques for Analyzing Industries and Competitors, New York: Free Press.

Porter, M. (1985). The Competitive Advantage: Creating and Sustaining Superior Performance. NY: Free Press.

Porter, M. (1998). Clusters and competition: new agendas for companies, governments, and institutions. Porter, M. On Competition, 197-287. Boston, MA: Harvard Business School Press.

Porter, M. (2003). The Economic Performance of Regions, Regional Studies, 37(6): 549-578.

Stănciulescu, G. (coord.) (2007). Tehnologia turismului. București: Editura Niculescu.

Tiessen, J., Linton, J. (2000). The JV dilemma: Cooperating and Competing in Joint Ventures, Canadian Journal of Administrative Sciences, 17(3): 203-216.
Van Mannen, J. (1979). The Fact of Fiction in Organizational Ethnography. Administrative Science Quarterly, 24(4): 539550.

Welch, C., Piekkari, R. (2017). How Should We (Not) Judge the 'Quality' of Qualitative Research? A Re-assessment of Current Evaluative Criteria in International Business. Journal of World Business, 52(4):714-725.

Yin, R.K. [1984] (2014). Case Study Research. Design and Methods. 5th ed. Thousand Oaks, CA: Sage.

\section{Internet resources:}

*** European Commission (2019). European Qualification Framework. Available at: https://ec.europa.eu/ploteus/en/content/descriptors-page (accessed at 30.07.2019).

*** Institute of Educational Sciences in Romania (2019). Programe școlare in vigoare. Available at: http://programe.ise.ro/Actuale/Programeinvigoare.aspx (accessed at 25.07.2019).

*** Ministry of Education in Romania (2019). Manuale scolare. Available at: https://www.manuale.edu.ro/ (accessed at 30.07.2019).

*** Romanian Education Law 1/ 2011. Available at https://www.edu.ro/sites/default/files/ fi \%C8\%99iere/Minist er/2017/legislatie\%20MEN/Legea\%20nr.\%201_2011_actual izata2018.pdf (accessed at 30.07.2019).

*** Scimago Journal Rank (2019). Available at: https://www.scimagojr.com/journalrank.php (accessed at 30.07.2019).

*** UNESCO (2019). International Standard Classifications of Education. Available at: http://uis.unesco.org/en/topic/international-standardclassification-education-isced (accessed at 30.07.2019). 